\title{
Studying the Indigo Child Types and How to Handle Them Based on the Novel Gerbang Dialog Danur Through Literary Psychology
}

Ninuk Lustyantie, Dhinar Ajeng Fitriany*, Emzir

Postgraduate of Universitas Negeri Jakarta, Jakarta, Indonesia

Corresponding Author: Dhinar Ajeng Fitriany, E-mail: dhinarajengfitriany@gmail.com

\section{ARTICLE INFO}

Article history

Received: February 24, 2018

Accepted: April 27, 2018

Published: September 01, 2018

Volume: 7 Issue: 5

Advance access: July 2018

Conflicts of interest: None

Funding: None

\begin{abstract}
Starting from the phenomenon of Indigo children who seize the attention of the people in several countries, including in Indonesia, the uniqueness of Indigo children becomes distinctive for Indigo children compared with other children in general. The uniqueness of Indigo children can be described by authors in literary works, such as novels. In addition, the uniqueness of Indigo children revealed in a novel can be used as a renewal in teaching novels reviewed using the literary psychology approach. The study of psychology in literature is an important thing to do with the aim of developing a way of teaching literature. However, the study of psychology in literature is still very less. In addition, research on Indigo children in literary works has never been done. In dealing with this problem, qualitative research using content analysis method with a literary structural approach and literary psychology of novel entitled "Gerbang Dialog Danur" written by Risa Saraswati was conducted. The result of the research is the phenomenon of Indigo children described by the main character, that is $A k u$ (Risa). In addition, this study also produced findings, namely the types of Indigo children and how to deal with them suggested in the novel. The results of this study conclude that Indonesian literary teachers, literary researchers, novel readers, parents, and the general public can use the novel Gerbang Dialog Danur by Risa Saraswati in the process of teaching literature, especially in the study of psychology.
\end{abstract}

Key words: Indigo Children, Indonesian Novel, Literary Psychology, Gerbang Dialog Danur

\section{INTRODUCTION}

In everyday life, literature can be found easily as well as in the teaching of literature because the literature has a function. Wellek \& Warren in Budianta (2014) explain that literature serves to teach something and can function as entertainment. Therefore, it can be seen that the teaching of literature is important to note so that learners can really get the wisdom of a literary work. Literary teaching, especially Indonesian literature, can arouse the interest of learners who study Indonesian literature to understand literature in depth. In order for learners to gain an in-depth understanding and wisdom of an Indonesian literary work, Indonesian literary teachers need to appreciate and love Indonesian literature and most important literary teachers can respect the creators of literary works. Endraswara (2008b) states that literary teaching itself can be done as a literary process and closely related to literary texts. Therefore, literary teachers can have to equip themselves first with the willingness to love the literature itself and understand the literary works of Indonesia as well. In addition, literary teachers can facilitate learners by presenting an interesting literary teaching and touching the learner so that learners can open themselves to literary works, learners can also interpret life through the contents of literary works, such as understanding the life of Indigo children.

In the teaching of literature, can be found learners with a different psychology. Therefore, literary teaching can be studied using literary psychology. Through literary psychology, learners will be motivated to understand the concept of psychology and literary teachers will better understand the psychology of learners. Emzir \& Rohman 2015) describe that literary psychology expresses the human problem which is displayed in the image of the soul into a story ready to be presented by the author. Stories that contain elements of psychology can touch readers, including touching the soul of learners. Through the psychology of literature, it can be seen that a closed story with the psychology will inspire the feelings of learners to better understand the different problems of each human, such as issues related to Indigo children.

The subject of Indigo children can be attributed to novel teaching in the sphere of language education, especially through novel study. It is closely related to everyday life, ie in everyday life can be found an individual or a group of Indigo society. In relation to the phenomenon of Indigo children, Soecipto (2011) explains that Indigo children are a new generation with a unique character compared to the previous generation. The uniqueness of Indigo children character that 
is used as a renewal in teaching novels reviewed using the approach of psychology literature. In addition, within the scope of language education, especially in the teaching of literature, it is possible that Indigo students with their unique character.

Starting from the phenomenon of Indigo which seizes the attention of people in several countries, including in Indonesia, Indigo's uniqueness can be seen clearly from some things in Indigo children. High sense of empathy in Indigo children to the surrounding environment, became one of the characteristics of Indigo children. Related to that, Puguh (2012) reinforces that there are characteristics that distinguish between generations of Indigo and generations in general, the generation of Indigo has a high sense of empathy. A high sensitivity of intuition fosters a high sense of empathy in Indigo children to the surrounding environment. Therefore, Indigo children appear more mature than others in general who his age.

The sensitivity of Indigo is closely related to Indigo types. There are four types of Indigo: humanist, conceptual, artistic (artist), and interdimensional (Bagnol, Ewing, \& Chu, 2011). Based on the type, Indigo has a different dominant sensitivity in itself. In addition, the diversity of these types also affects Indigo's interest in a field. In addition, Indigo is a person who was born with the color of aura body "indigo". Indigo aura colors are closely related to the activation of the sixth chakra in their body, called the Ajna chakra or third eye chakra. The sensitivity of the third eye chakra that is owned by Indigo children can also affect the psychic of Indigo children. Indigo children can often experience emotional chaos. Carroll \& Tober in Hendy (2006) also argue that Indigo children may experience emotional chaos with others who are unable to understand Indigo children. Indigo children have high self-esteem with strong integrity. It can affect Indigo's emotions if they are dealing with others who do not understand their characteristics.

The emotional chaos of Indigo is also related to his ability to create conscious decisions of his mind. His high self-integrity can become weak when encountered with destructive thoughts. Condron in Murtihardjana (2007) states about one suggestion that can be given to Indigo to develop the potential and increase his power in thinking, namely by communicating his thoughts in verbal form. Writing becomes one of the recommended handlings for Indigo in controlling all forms of emotion. Through writing, Indigo can express his thoughts in a more socially beneficial form, both himself and others.

In the novel, the subject of Indigo children can be represented by the main character in the novel. Through a novel, it can be revealed that Indigo children's portrayal is related to Indigo types and handling can be done related to Indigo children. The subject of Indigo children contained in the novel can be studied using literary psychology. This shows that the novel has a relationship with the field of psychology.

The phenomenon of Indigo children found in the novel is an object motivates researchers to deeply analyze the Indigo children. This is because during this teaching of literature in formal education has never done the study. As for this, it provides a renewal in analyzing and reviewing novels that reveal the Indigo children through the main character. This can be a new research in the field of language and literature on the handling of Indigo children in the novel. Updates in analyzing and reviewing Indigo children in the novel can provide positive benefits for learners in understanding the uniqueness of Indigo children, especially about Indigo types and handling of Indigo children.

In connection with the subject of Indigo children, there is a novel that contains a description of Indigo children. The novel is entitled Gerbang Dialog Danur written by Risa Saraswati (2016). The novel is about the self-confession of Indigo children named Risa Saraswati who since childhood has the sensitivity to see, hear, and interact with astral beings or supernatural beings, which are generally called ghosts, until the story of her friendly with five ghosts of little Dutch children, Peter, Hans, Hendrick, William, and Janshen. Risa Saraswati as the novel writer is able to describe in detail and logical about Indigo which represented by herself as the main character of $A k u$ (Risa) in the novel of Gerbang Dialog Danur. Indigo in Risa is clearly expressed through dialogue quotes, behavioral depictions, and movements of the main character who supports the disclosure of Indigo children to the main character. The novel Gerbang Dialog Danur is the work of Risa Saraswati, an Indigo in real life every day, full of deep psychological elements, which is about the Indigo child.

Risa Saraswati is also able to imply all the ghost stories she wrote in the novel Gerbang Dialog Danur and which is really there and have experienced. The ability of Risa to reveal the historical side of the cause of death of the ghosts who had interacted with her in a logical and detailed also became the reason why researchers chose to examine the novel. In addition, the style of an honest and easy to understand writer also facilitate the reader in understanding the story, especially about Indigo in the novel. Risa also packs interesting story content about Indigo which is loaded with the message of life and humanity. Risa with her indigo has since childhood can be a positive lesson for readers, both readers who also include Indigo and non-Indigo.

Through the interesting aspects contained in the novel Gerbang Dialog Danur, strengthen the researcher's assumption that the novel deserves to be examined with the approach of literary psychology related to the study of Indigo children. Researchers also assumed that the novel of Risa Saraswati's Gerbang Dialog Danur will interest students in studying Indonesian literature, especially studying novels. The uniqueness of the story and background of a novel writer who is also an Indigo child can enhance the enthusiasm of learners to deepen about the Indigo children through novels, one of which is the novel of Gerbang Dialog Danur by Risa Saraswati. Another positive consideration is the reason why researchers research the novel of Risa Saraswati's Gerbang Dialog Danur because the novel has been reprinted six times, with the sixth published in January of 2016. It shows that the public appreciation of the novel of Gerbang Dialog Danur by Risa Saraswati is very positive. Risa Saraswati's novel of Gerbang Dialog Danur also has 
other features, which reinforce the researcher's assumption that the novel is worthy of being studied as a literary psychology research, the novel being made into a widescreen film entitled Danur on March 30, 2017. The novel is special and able to exceed the number of a million spectators, exactly as many as $1,196,583$ spectators, just within a week after the film Danur release in cinemas in Indonesia. The rapid number of viewers who watched the Danur movie in a short time, making Jaya Suprana, as Chairman of MURI (World Record Museum of Indonesia), awarded the $7800^{\text {th }}$ MURI to that film. This is because the achievement of the number of Danur movie viewers is the largest number of horror movie viewers in Indonesia.

The focus of this research is to study the types of Indigo children and how to handle them based on the novel Gerbang Dialog Danur through literary psychology. There is two sub focus research, namely how the types of children Indigo on the main character, and how to handle the Indigo child in the main character. The general purpose of this study is to gain a deep understanding of the handling of Indigo children based on Indigo child types based on the novel Gerbang Dialog Danur through literary psychology. The specific purpose of this study is to gain a deep understanding of the types of children in the main characters in the novel and gain a deep understanding of how Indigo children handle the main characters in the novel.

In relation to the study "Studying the Indigo Child Types and How to Handle Them Based on the Novel Gerbang Dialog Danur Through Literary Psychology", found ten relevant studies, namely: (1) Trauma Theory: No "Separate Peace" article for Ernest Hemingway's " Hard-Boiled "Characters by Salam \& Abualadas (2017) that result in the conclusion that considering traumatic memories as" impossible events "helps us to see why Hemingway's warriors have difficulty due to their inability to sleep and are unable to adapt socially, and even that figure also tries to remember "Impossible events" by forcibly remembering them as disturbing and late memories as a form of sad memories and nightmares. This research is relevant because it is both about human and psychology; (2) research article Cosmic Mysticism: The Quest for the Absolute in the Works of Tagore and Sri Aurobindo by Samantaray (2017) which results in the conclusion that cosmic mysticism is a manifestation of the human religious side, as fully individual, social, economic, political and environmental physical reconstruction Budata through the incarnation of divine power. Samantaray (2017) states that two poems, Tagore's poetry, and Aurobindo poetry, express their spiritual experience strongly in multi-nuanced poetry. This research article is relevant because it is equally discussed the literary works that contain the spiritual intuition of the individual who is the awareness of their religious side; (3) research article by Mohammad Amin Shirkhani who produced the conclusion that the role of female character in Paul Auster's New York Trilogy and In the Country of the Last Things seen from the post-structuralist, psychoanalytical perspective, Auster's body works on the understanding of gender stratification in American society and the tale that can not be separated from male concentration (Shirkani, 2017). This research article is relevant because it equally discusses the female characters in literature and psychology; (4) research article Teaching with Literature: The Needs of Indonesia Islamic Universities by Irwansyah, Nurgiyantoro, \& Tou (2017) who stated that the teaching of English and literature will be effective when utilizing short stories with various topics such as Nobel characters, self, freedom, code of deed, and greed of someone. Stories must relate to Islamic values and be equipped with a glossary of difficult words, phrases, and expressions. Research articles are relevant because they both discuss literature; (5) research article Development of Indigo Check List: The Concern of Malaysian Society for Needs of Indigo Children by Yong \& Arip (2015) concluded that parents in Malaysia can better know and understand their children as Indigo children if parents can really pay attention to the characteristics of Indigo children, as for example, Indigo children in school are reluctant to engage in discussion, not happy to follow the rules. This research is relevant because it is equally about Indigo children; (6) Research article Children Who Claim to Remember Previous Lives: Past, Present, and Future Research by Tucker (2007) who concludes that children who can know and see events that have occurred in the past, including seeing the suffering of others in the past. This research is relevant because it deals with gifted children, such as Indigo children, who share the ability to understand the past; (7) The Arizona Kith and Kin Project Evaluation research article by Shivers, Farago, \& Goubeaux on Indigo children's handling based on Indigo children's characteristics (2016). This research is relevant because it is equally about Indigo children and how to handle Indigo children; (8) Research article Countervailing Forces: Religiosity and Paranormal Belief in Italy by Bader, Baker, \& Molle (2012) who produced the conclusion that the paranormal can have a relationship with one's religious side. A paranormal subject can make a person more religious or even less of its religious sense. The paranormal activity studied was astrology, communication with the dead, hand line reading, telepathy, and spirit. This is relevant to the research in this dissertation that Risa can communicate well. Risa also keeps her religious side;(9) Research article Understanding the Social and Emotional Needs of Gifted Children by Murdock-Smith (2013) stating that there are children who have a unique in social and emotional. Such children need to be understood. They are difficult to express their feelings so they need to be reassured that they are special. Indigo is a special and different child. This research is relevant to the dissertation because it equally discusses that gifted children, Indigo needs to be understood, not judged, and believed that they are special. In this study, Indigo children, i.e. figure $A k u$ (Risa) also want to be understood and not considered weird; and (10) The Ghost in The Machine research article by Tandy \& Lawrence (1998). Lawrence which results in the conclusion that the supernatural being exists and can be investigated through seismic activity, noise, electromagnetic, and object displacement. Supernatural beings can be known to show their existence through various mediums. This is relevant to this Indigo study. The character $A k u$ (Risa) knows the presence of supernatural beings through the sounds, the displacement of objects around it. 
Relevant research articles include discussions on humans, psychology, literary works containing spiritual intuitions, psychoanalytic perspectives, female literary figures, Indigo child characteristics, and the handling of Indigo children. However, from relevant research articles, no research has been done to discuss Indigo children in novels, especially about Indigo types and handling of Indigo children through the main characters in the novel, such as this research. Based on the relevant study described in the previous paragraph, research in studying Indigo child types and how to handle Indigo children in novels needs to be done. This is because studying the types of Indigo children and how the handling of them in literary works, especially novels, has never been analyzed. Therefore, researchers have a great motivation to do research "Studying the Indigo Child Types and How to Handle Them Based on the Novel Gerbang Dialog Danur Through Literary Psychology", to understand deeply about Indigo children in the novel represented by the main character, that is $A k u$ (Risa). In addition, research into the types of Indigo children and how Indigo children's handling of Indonesian novels can provide a renewal in the realm of language and literature, especially in the teaching of literature. Through literary teaching that discusses novels that contain the handling of Indigo children, learners are invited to appreciate the literary works that contain Indigo children and the work of Indigo children, learners are also invited to appreciate and handle the Indigo children through the depiction of Indigo children described by the main character in the novel, as in the novel of Gerbang Dialog Danur by Risa Saraswati with the main character $A k u$ (Risa).

\section{LITERATURE REVIEW}

A counselor named Nancy Ann Tappe was the first to identify and write about the Indigo phenomenon in his book Understanding Your Life Through Color in 1982. Tappe in Hendy (2006) explains that Indigo is the color of life where people related to their mission on earth and what they will do on earth. This indicates that Indigo is a person who has a new set of psychological attributes with extraordinary thought and body color that is considered a sign of human presence that is expected to improve the life of the world for the better. Indigo's aura is closely related to a spiritual activity.

Indigo is considered a person who has higher spiritual and intuitive abilities than people in general. This is reinforced by Healy (2013) who explains that "Indigos have a strong energy of defiance, stubbornness, and also sweetness along with their deep sensitivity." Regarding this, it can be seen that Indigo has a strong energy inside. In addition, Indigo is also a stubborn figure but has a high sensitivity compared to others in general. Indigo is also regarded as a spiritual man, as the researchers pointed out from Condron in Murtihardjana's explanation (2007) that the Indigo child is a Spiritual Man with high intuition. Indigo is a person who wants to be responsible for learning and they are individuals who want to teach. Based on this, it can be understood that the high intuition ability of Indigo makes them as a spiritual and wise person. The high intuitive ability of Indigo makes them often think analytically about a thing.
The unique patterns of behavior and way of thinking of Indigo children form a diversity among them. The diversity of behavior makes Indigo grouped into four types. The types of Indigo consist of the type of humanism, the type of conceptual, type of artist or artistic type, and interdimensional type (Puguh, 2012). Indigo humanist type has a sensitive sense of the social environment. Indigo with the conceptual type always thinks according to what she thinks is right. Meanwhile, Indigo artistic types are very fond of art and their work as a professional. Indigo artistic type has a sensitive and creative soul. In addition, Indigo with an artistic type is able to show interest in herself in 5 or 6 areas of art, but her adult interests are focused on only one field that she has mastered well. Indigo interdimensional types can interact with other creatures, such as supernatural beings. In relation to Indigo types, Indigo children sometimes do not have only one type but can be two or more with one type as the dominant type.

The uniqueness of Indigo children's behavior patterns and ways of making people closest to them, especially families, should be able to treat Indigo children wisely. In addition, good and wise handling is also needed in response to Indigo children. Carroll \& Tober (2008) have described the previous Indigo handling. Based on the previous explanation, the researcher in this study analyzed ten handling of Indigo children, among others: giving affection to the Indigo, 2) avoiding giving orders to the Indigo, 3) not using abusive language to the Indigo, 4) always be honest to the Indigo 5) worship, 9) increase concentration by writing, and 10) aloof to balance thoughts and feelings.

In the teaching of literature, so that learners can gain a deep understanding and wisdom in literary works, literary teachers need to appreciate, love, and most importantly appreciate the creators of literary works. This can be based on Endraswara's (2008b) statement that literary teaching itself can be done as a literary process and closely related to literary texts. Therefore, teachers can equip themselves first with the willingness to love the literature itself and understand the literary works of Indonesia as well. In addition, literary teachers can facilitate learners by presenting an interesting literary teaching and touching the hearts of learners so that learners can open themselves to literary works, including content about Indigo children in it.

Based on the previous paragraph, Rohman (2012) reinforces that literary teaching is an interactional process for building literary knowledge. Therefore, it can be seen that in the teaching of literature, literature lecturers attempt to release their insight by participating and involving learners so that interaction is created well, one of the teachers seeks to understand the life of Indigo children depicted in the contents of literary works.

In relation to literary psychology, Endraswara (2008a) explains that language in literature is a psychological symbol. The literary language contains deep psychic meanings and psychological symptoms can be examined behind the language. Through the explanation of Endraswara, it can be seen that literary psychology is worthy of research related to 
language education. This is because, learners can be more taught by teachers to understand the language in literature, especially Indonesian, through a review based on literary psychology, such as about Indigo in the novel.

The novel which is a reflection of truths that conforms to everyday reality can be explained scientifically. In this regard, Eagleton (1996) points out, "The literary work was neither a vehicle for ideas, a factual factor, nor an engineer."From that explanation, it can be analyzed that literary works were created by authors as a form of reflection on the social realities that occurred in real life, and not formed through things that can not be analyzed using scientific explanations.

The novel as a form of literary work of prose fiction can contain various depictions of human real life. This is reinforced by Emzir \& Rohman (2015) which states that as a form of expression of the reality of human life that is figurative, a literary work is a representation of all events in society. Based on that explanation, it can be analyzed that a novel as one of the literary works is a reflection of real human life that can reflect its readers to gain more interesting and dynamic knowledge. This is because literary works are created by authors by following the phenomena that occur in society.

The inspiration of an author becomes an important thing an author must have in the process of creating literary works, such as novels. Related to that, Nurgiyantoro (2000) suggests the author's experience, observations, and thoughts of the factual truth of life affecting the author in the creation of a novel. The author's inspiration is created through experience and observation experienced and obtained by the author's sense of life.

Based on these matters, it can be synthesized that the novel of the Gerbang Dialog Danur by Risa Saraswati, as one of literature, is an interesting and worthy novel. The novel of Gerbang Dialog Danur by Risa Saraswati that describes the subject of Indigo, comes from the author's own experience, Risa Saraswati. The story ideas inspired by the real-life experienced by the author become one of the positive points that reinforce that the novel Gerbang Dialog Danur by Risa Saraswati feasible to be studied using literary psychology. This is because the description of Indigo in the novel is closely related to the realm of psychology.

The subject of Indigo can be attributed to the teaching of novels within the scope of language education and applied linguistics, especially through novel study. It is closely related to everyday life, ie in everyday life can be found an individual or a group of Indigo society. Regarding the Indigo phenomenon, Soecipto (2011) explains that Indigo is a new generation with a unique character compared to previous generations. The uniqueness of Indigo characters is what can be used as a novelty update in novel teaching which is studied using literature psychology approach. In addition, within the scope of language education, especially in novel teaching, it is possible to find Indigo students with their unique character.

Indigo students have unique characteristics from other general students. The uniqueness of Indigo's learner character is related to high intuition and spiritual ability. In addi- tion, Indigo students are born with wise old souls and have high analytical skills compared to other common learners. The uniqueness of Indigo learner characters is the reason that they need special treatment compared to other general students in education. This is because Indigo students generally do not like the world of learning in a formal school environment full of rules. They are individuals with high creativity, so they need a flexible learning environment, do not require a lot of rules to adhere to, and a learning space that can support Indigo students in expressing their unique ideas.

In the social sphere, Indigo is often associated with attention dysfunction and hyperactivity. Indigo students can experience emotional chaos when faced with people who are not able to understand their indigo. However, on the other hand, Indigo students have high intellectuals compared to other general students. Their ability to explore ideas is expressed through writing activities. Through writing activities, Indigo students can train their mental concentration and control their emotions. These things reinforce that within the scope of language education, Indigo students are included in the category of learners who have exceptions. Regarding this, Slavin (2011) explains that the term learners with exceptionalities can be used to describe any person whose physical, mental, or behavioral performance seems so different from the ordinary, both higher and lower, so additional services are needed to meet the person's needs. In accordance with the explanation Slavin, it can be seen that Indigo students included in the category of learners who have an exception because of their needs in learning is different from the needs of other general students, so that teachers should be able to provide special treatment in support of Indigo students learning activities.

In relation to the existence of categories of learners who have exceptions, inclusion is one of the educational environments that can support the learning activities of Indigo students. Regarding inclusions, Slavin reinforces that inclusion is often called mainstreaming focused on students with learning disabilities, mild backwardness, and mild emotional distress, whose shortcomings can be termed "mild academic incompetence". Through this explanation, it can be seen that inclusion facilitates classes that place learners with special needs into the public education classroom. Inclusion can support Indigo students in improving their achievements and confidence in the community environment. In addition, teachers equipped with special education services related to inclusion can help Indigo students to understand learning maximally. Inclusion can also create a fun and communicative learning atmosphere, where Indigo students can interact with their age friends and learn the behavior of other learners.

The existence of the phenomenon of Indigo children in the novel, inspiring researchers to analyze it with more depth. This is remembered, in the teaching of novels that have been carried out in the formal education field has never tried to give renewal in analyzing and reviewing novels that reveal Indigo through the main character. Updates in analyzing and reviewing Indigo in addition to providing theoretical benefits for learners can also provide practical benefits for 
learners in understanding the uniqueness of Indigo children.

In the novel, the subject of Indigo can be represented by the main character in the novel. Through a novel, it can be expressed by the depiction of Indigo children related to the types of Indigo and the handling that can be done related to Indigo children. In connection with Indigo children, there is a novel that reveals about Indigo children in it, the novel Gerbang Dialog Danur by Risa Saraswati.

Novel Gerbang Dialog Danur tells about Indigo self-confession named Risa Saraswati who since childhood has the sensitivity to see, hear, and interact with astral beings or supernatural beings, commonly called ghosts, until the story of her self-friendly with five ghosts of little Dutch children, i.e Peter, Hans, Hendrick, William, and Janshen. Risa Saraswati as a novel writer able to describe in detail and logical about Indigo which represented by herself as the main character of I/Aku (Risa) in the novel Gerbang Dialog Danur.

\section{METHOD}

The approach used in this research is qualitative approach with content analysis method. Furthermore, the literary approach used is literary psychology. This research is conducted through searching data from books that support research, internet, and data observation about Indigo children in the novel of Gerbang Dialog Danur by Risa Saraswati. The data source used in this research is the novel of Gerbang Dialog Danur by Risa Saraswati.

In this research, there are seven stages of data collection procedure, namely (1) Reading the novel Gerbang Dialog Danur by Risa Saraswati, (2) Looking for interesting phenomenon in novel content of Gerbang Dialog Danur by Risa Saraswati, (3) Establishing Indigo on Gerbang Dia$\log$ Danur by Risa Saraswati as the data in the research, (4) Establish the novel of Gerbang Dialog Danur work by Risa Saraswati as data source in research, (5) Establish content analysis as research method, (6) Establish structural approach and approach of literature psychology as research approach, (7) conducting literature study, observation of Indigo children in novel, and interview study.

In the data analysis procedure, the researcher analyzes the depiction of Indigo child types and the handling of Indigo children. The researchers also created a recapitulation table and a summary table of work.

\section{RESULT AND DISCUSSION}

\section{How Types of Indigo Children on the Main Characters in the Novel Gerbang Dialog Danur by Risa Saraswati?}

Based on the observation of Indigo child types on the main characters in the novel, 36 descriptions were obtained (Table 1).

Based on Indigo types, the discussion of how the Indigo child types are of the main character $A k u$ (Risa), i.e humans' type, conceptual type, artistic type, and interdimensional type. The humanist type is Indigo who has a sensitive sense of social environment, is friendly, and has a hyperactive side
Table 1. Working table of the number of observation data for types of indigo on the main character of the novel gerbang dialog danur by Risa Saraswati

\begin{tabular}{llcc}
\hline No. & Types of indigo & $\begin{array}{c}\text { Number of } \\
\text { observation } \\
\text { data (Quote) }\end{array}$ & Percentages \\
\hline 1. & Humanist & 9 & 25.00 \\
2. & Conceptual & 5 & 13.89 \\
3. & Artist & 5 & 13.89 \\
4. & Interdimensional & 17 & 47.22 \\
Total & & 36 & 100 \\
number & & & \\
\hline
\end{tabular}

that makes them feel awkward with their own bodies. The conceptual Indigo type is Indigo who always thinks according to what he thinks is right, so the conceptual Indigo type is often against the rules. Indigo type artist (artistic) is Indigo who loves art and their work as a professional artist, has a creative soul, and they will express their creative side in their work. Indigo Interdimensional type is Indigo that can interact with invisible beings, has a very big tendency in the realm of philosophy and religion, and usually, this type is rather difficult to interact with others in general.

Based on the types of Indigo children on the main character in the novel of Gerbang Dialog Danur by Risa Saraswati, it can be concluded that the Indigo Interdimensional type dominates the contents in the novel because the main character $I / A k u$ (Risa) has the sixth natural senses since Risa was born, so it makes Risa can see and interact with invisible beings and befriends five astral beings in the form of a Dutch boy, named Peter, William, Hans, Hendrick, and Janshen. In addition, the wise and philosophical side of Risa in response to her life problems and the experiences experienced by the surrounding astral beings support the Indigo Interdimensional type on the character Risa. It is revealed through the main character $A k u$ (Risa) who is a good listener for invisible beings who tell their experience to the character $A k u$ (Risa). In addition, $A k u$ (Risa) also filter all the tales of invisible beings into the head, brain, and ears, though often Risa does not understand everything. The philosophical side that reinforces the dominance of the Indigo Interdimensional type on the main character $A k u$ (Risa) is also revealed through $A k u$ (Risa) who thinks that from the negative things there are still positive things taken by herself as a lesson for the character $A k u$ (Risa). The main character $A k u$ (Risa) also realizes that as an Indigo woman, she is very grateful for being blessed with the ability to interact with astral beings. The Interdimensional Indigo type that dominates the character of Risa can also be seen through Risa's attitude. Although Risa can communicate with the surrounding astral beings, it does not mean Risa does not believe. Risa is very grateful to God and remembers God.

Valle (2008) stated that in 2006, at the University of Central Oklahoma there were 439 students who believed in haunted houses, psychics (paranormal), ghosts, demons, spirits, reincarnations, telepathy, and other mysterious things. It is in accordance with the character I/Aku (Risa) Indigo Interdimensional show even since Risa sat in elementary school. 
Risa is able to interact with astral beings since she was little. In addition, the dominance of the Interdimensional type on the main character $A k u$ (Risa) shows the high psychic ability of Risa. Wiseman, West, \& Stemman(1996) explained that one's psychic abilities can help people solve investigations and predict things. This is in accordance with the character of Risa who also did help, but that assisted Risa is an astral creature. Risa is able to investigate the problems of astral beings and help her so that the astral beings can leave her.

\section{How to Handle Indigo Children on the Main Characters in the Novel Gerbang Dialog Danur by Risa Saraswati?}

Based on observations on the handling of Indigo children in the main characters in the novel, 12 descriptions were obtained (Table 2).

Based on the handling of Indigo children, the discussion on how the handling of Indigo children on the main character $\mathrm{I} / A k u$ (Risa), which gives love to the Indigo, avoid giving orders to the Indigo, do not use harsh language to the Indigo, always honest to Indigo, develop talent, meditation, developing awareness and dreams, worshiping, increasing concentration by writing, and being alone to balance thoughts and feelings.

In relation to the handling of Indigo to the main character in the novel of Gerbang Dialog Danur by Risa Saraswati, it can be concluded that developing awareness and dreams dominated the contents of the novel in the main character Aku (Risa). The main character Aku (Risa) realizes that her life is happy and well. Risa also develops her consciousness and dreams through her own thinking that as an Indigo child, she feels fortunate to have the ability to interact and see invisible beings, where not everyone has it and experiences it. In addition, Risa also develops her dreams by convincing herself as an Indigo child, Risa can help invisible beings in finding solutions to their problems. Risa also realizes that her ability as an Indigo child who can interact and see invisible beings is a gift from God for her and she should be grateful. In addition, Risa also realizes that as an Indigo child, motivate Risa to gather with other Indigo and enjoy the grace from God to her to help the astral creatures who meet her in solving their problems. The main character $A k u$ (Risa) has a talent in the field of music, namely singing. In addition, Risa also has the greatest dreams that want to be developed and realized, namely to write songs, sing it, record it, and release it into an album. Risa also realizes that she is still hoping her fifth best friend who invisible to see her at this time. In addition, Risa also realizes that she is a human being who used to put expectations on something she may not be able to achieve. As for that, motivating Risa to develop her awareness and dreams related to her five invisible friends, by seriously recording some of the songs she wrote, including the song she wrote for her five best friends, entitled "Story of Peter", as a song mainstay in the album.

In the handling of Indigo children in the form of increasing concentration by writing is also discussed on the character Risa revealed that she increased her concentration when imagining how she met her five invisible friends, namely Peter, William, Hans, Hendrick, and Janshen, by writing some verses lyrics a song that tells about her fifth best friend. In addition, the song written by Risa is a song she dedicated to her five invisible friends. As for writing does increase one's concentration, it can also heal a person. Tyler (2000) explains that writing, like writing about sadness, will add value, helping people to understand suffering as well as conditions. Based on these explanations, it can be analyzed that writing is a positive activity. By writing, the character $A k u$ (Risa) in the novel was able to devote her thoughts about her invisible friends. By writing also, Risa can control her mind related to the occult.

\section{CONCLUSION}

In a study related to "Studying the Indigo Child Types and How to Handle Them Based on the Novel Gerbang Dialog Danur Through Literary Psychology", obtained two conclusions, namely (1) Indigo Interdimensional type dominates the contents of the novel because the main character $A k u$ (Risa) has gift from God the sixth senses acquired naturally since Risa was born, thus making Risa able to see and interact with invisible beings, so that Risa can be friendly with five astral beings in the form of a Dutch boy named Peter,

Table 2. Working table of the number of observation data for the handling of indigo on the main character in the novel Gerbang Dialog Danur by Risa Saraswati

\begin{tabular}{llcc}
\hline No. & Handling of indigo & Number of observation data (Quote) & Percentage \\
\hline 1. & Giving affection to the indigo & 1 & 8,33 \\
2. & Avoid giving orders to the indigo & 0 & 0 \\
3. & Do not use harsh language to indigo & 0 & 0 \\
4. & Always be honest to the indigo & 0 & 0 \\
5. & Develops talent & 1 & 8,33 \\
6. & Meditation & 0 & 0 \\
7. & Develop awareness and dreams & 4 & 33,33 \\
8. & Prayer & 2 & 16,67 \\
9. & Increase concentration by writing & 2 & 16,67 \\
10. & Alone to balance thoughts and feelings & 2 & 16,67 \\
Total number & & 12 & 100 \\
\hline
\end{tabular}


William, Hans, Hendrick, and Janshen. In addition, Risa's wise side and philosophy in response to her life problems and problems that occur in the invisible beings around her support the Indigo Interdimensional type on the main character $A k u$ (Risa). Although Risa can interact with invisible beings around her, it does not mean she does not believe. Risa is always grateful for God's gifts to her and she always remembers God. The Interdimensional Indigo Type in Risa makes Risa closer to God, and (2) Risa handles her indulgence through developing her consciousness and dreams. The main character $A k u$ (Risa) realizes that she was born as an Indigo child who is God's gift to her. Risa realized that Indigo children are just ordinary people who have advantages and disadvantages. The indigo of Risa often make her feel dilemma, Risa realizes that she must be strong in the face of her life and thank God for God's gift to her. As an Indigo child, Risa also has the same dreams as people in general. Risa also has a desire to develop her talents and talents in the field of music, through writing, creating and releasing her songs into an album dedicated to her five astral friends.

Concerning the realm of education, especially language and literature, the results of this research can be recommended for literature teachers and learners who study literature to explore their thoughts and knowledge about Indigo children and literary psychology, especially in learning how to handle Indigo children and Indigo types through literature, as in the Indonesian novel, the novel Gerbang Dialog Danur by Risa Saraswati. In addition, the results of this study can enrich the renewal of literary research and can be used as a reference in the teaching of language education, literature, and applied linguistics.

This research may be recommended for literature teachers as a reference in subsequent research in the realm of language and literature that examines Indigo children, especially in literary works. Therefore, literary researchers are expected to do more literary psychology because the research provides positive benefits, especially in an effort to better understand and deepen the psychology of literary students related to the teaching of literature and also applied linguistics.

For novel readers, this research can be recommended to novel readers in order to obtain the wisdom of the novel Gerbang Dialog Danur by Risa Saraswati, among others to better understand the Indigo children, not to excommunicate, not to consider strange Indigo children, and more appreciate Indigo children.

This research can be recommended for parents, can be expected to always guide, direct, give positive education to children, especially children Indigo, Indigo children sincerely, never be rude or shout Indigo children, and always listen to opinions and thoughts of Indigo children in the family.

In addition, the results of this study can be recommended for everyone in general, especially non-Indigo people, in order that non-Indigo can learn to be more accepting, understanding, respecting, respecting and loving the Indigo so that the Indigo avoid the sense of alienation in the surrounding environment.

\section{REFERENCES}

Bader, C. D., Baker, J. O., \& Molle, A. (2012). Countervailing Forces Religiosity and Paranormal Belief in Italy. Journal for the Scientific Study of Religion, 51(4), 705706.

Bagnol, L., Alexander, J., Ewing, H., \& Chu, D. (2011). Indigos in Hawai'i: a Penomenological Study of the Experience of Growing Up with Spiritual Intelligence. Pacific Health Dialog, 17(1), 83-98.

Budianta, M. (2014). Teori Kesusastraan. Jakarta: Gramedia Pustaka Utama.

Carroll, L., \& Tober, J. (2008). The Indigo Children: Ten Years Later. USA: Hay House.

Murtihardjana, L. (2007). How to Raise an Indigo Child: 10 Kunci untuk Mengolah Kecerdasan Anak Indigo. Jakarta: Bhuana Ilmu Populer.

Eagleton, T. (1996). Literary Theory: An Introduction (Second Edition). Oxford: Blackwell Publishing.

Emzir, E., \& Rohman, S. (2015). Teori dan Pengajaran Sastra. Jakarta: RajaGrafindo Persada.

Endraswara, S. (2008a). Metode Penelitian Sastra: Teori, Langkah, dan Penerapannya. Yogyakarta: MedPress.

Endraswara, S. (2008b). Metodologi Penelitian Sastra: Epistemologi, Model, Teori, dan Aplikasi. Yogyakarta: MedPress.

Healy, M. D. (2013). The Energetic Keys to Indigo. New Jersey: New Page Books.

Hendy, T. (2006). The Indigo Children. Jakarta: Bhuana Ilmu Populer.

Irwansyah, D., Nurgiyantoro, B., \& Tou, A. B. (2017). Teaching with Literature: The Needs of Indonesia Islamic Universities. International Journal of Applied Linguistics \& English Literature, 6(7), 169-179.

Murdock-Smith, J. (2013). Understanding the Social and Emotional Needs of Gifted Children. Rivier Academic Journal, 9(2), 1.

Nurgiyantoro, B. (2000). Teori Pengkajian Fiksi. Yogyakarta: Gadjah Mada University Press.

Puguh, O. (2012). Buku Lengkap tentang Anak Indigo. Yogyakarta: FlashBooks.

Rohman, S. (2012). Pengantar Metodologi Pengajaran Sastra. Yogyakarta: Ar-Ruzz Media.

Salam, W.,\& Abualadas, O. (2017). Trauma Theory: No "Separate Peace" for Ernest Hemingway's "HardBoiled" Characters. International Journal of Applied Linguistics \& English Literature, 6(7), 97-102.

Samantaray, S. (2017). Cosmic Mysticism: Quest for the Absolute in the Works of Tagore and Sri Aurobindo. International Journal of Applied Linguistics \& English Literature, 6(1), 298-304. Retrieved from i:10.7575/aiac. ijalel.v.6n.1p.298

Saraswati, R. (2016). Gerbang Dialog Danur. Jakarta: Bukune.

Shirkani, M. A. (2017). Configuration of the Self-Mythology and Identity of Female Characters in Paul Auster's In the Country of Last Things and The New York Trilogy. International Journal of Applied Linguistics \& English Literature, 6(7), 81-87. 
Shivers, E. M., Farago, F., \& Goubeaux, P. (2016). The Arizona Kith and Kin Project Evaluation: Improving Quality in Family, Friend, and Neighbor (FFN) Child Care Settings. Indigo Cultural Center, 6.

Slavin, R. E. (2011). Psikologi Pendidikan: Teori dan Praktik: Edisi Kesembilan Jilid 2. Jakarta: Indeks.

Soecipto, N. A. (2011). Rahasia Besar Anak Indigo: Dilengkapi Mengenali Indera Manusia. Yogyakarta: IN AzNa Books.

Tandy, V., \& Lawrence, T. (1998). The Ghost in The Machine. Journal for The Scientific Study of Religion, 62(851), 1.

Tucker, J. B. (2007). Children Who Claim to Remember Previous Lives: Past, Present, and Future Research. Journal of Scientific Exploration, 21(3), 543.
Tyler, L. (2000). Narratives of Pain: Trauma and The Healing Power of Writing. Journal of The Assembly for Expanded Perspectives on Learning, 5, 21.

Valle, J. M. (2008). Effects of Social Influence and Persuasion on Paranormal Beliefs. Journal of Undergraduate Psychological Research, 3, 47.

Wiseman, R., West, D., \& Stemman, R. (1996). An Experimental Test of Psychic Detection. Journal of the Society for Psychical Research, 61(842), 34.

Yong, Y. M., \& Arip, M. A. B. M. (2015). Development of Indigo Checklist: The Concern of Malaysian Society for Needs of Indigo Children. International Journal of Education and Research, 3(10), 24. 